\title{
Polikistik Over Sendromunda Güncel Terapötik Ajanlardan İnositol ve Alfa Lipoik Asit Takviyesi Üzerine Bir Derleme
}

\author{
A Review on Inocytol and Lipoic Acid Reinforcement from \\ Current Therapeutic Agents in Polycistic Over Syndrome
}

\author{
Selma FIRAT ${ }^{1}$, Mehmet FISUNOĞLU ${ }^{2}$
}

Yazışma Adresi

Correspondence Address

\section{Selma FIRAT}

Kırklareli Üniversitesi Sağlık Yüksekokulu Beslenme ve Diyetetik Bölümü, Kırklareli, Türkiye

E-posta: agslmfirat@gmail.com, selmafirat@klu.edu.tr
${ }^{1}$ Kırklareli Üniversitesi Sağlık Yüksekokulu Beslenme ve Diyetetik Bölümü, Kırklareli, Türkiye

${ }^{2}$ Hacettepe Üniversitesi Sağlık Bilimleri Fakültesi Beslenme ve Diyetetik Bölümü, Ankara, Türkiye
Geliş tarihi \ Received : 21.01 .2020 Kabul tarihi \Accepted : 08.05.2020 Elektronik yayın tarihi $\quad: 12.07 .2021$ Online published

Bu makaleye yapilacak atıf: Cite this article as:

Firat S, Fisunoğlu M. Polikistik over sendromunda güncel terapötik ajanlardan inositol ve alfa lipoik asit takviyesi üzerine bir derleme. Akd Tip D $2021 ;(7) 2: 184-196$

Selma FIRAT ORCID ID: 0000-0003-1477-2194 Mehmet FISUNOĞLU ORCID ID: 0000-0002-0021-7811
ÖZ

Polikistik over sendromu (PKOS) üreme çă̆ındaki kadınlarda görülen bir endokrin bozukluk olup, üreme, hormonal ve metabolik anomalilere neden olur. İnsülin direncinin (ID) eşlik etmesi nedeniyle PKOS tedavisi için insülin duyarlaştırıcı özelliği bulunan farklı terapötik ajanlar da kullanılmaktadır. İnsülin duyarlaştırıcı özelliği bulunan inositol ve antioksidan özelliği olan alfa lipoik asit de bu terapötik ajanlar arasında yer almaktadır. İnositol (myo-inositol ve di-chiroinositol), ikincil bir haberci olarak insülin sinyal iletimi transdüksiyonunda rol alan ve PKOS tedavisinde etkili olduğu gösterilen bir besin takviyesidir. Yapılan çalışmalar, inositol takviyesi ile PKOS'lu kadınlarda yumurtlama hızı, adet döngüleri ve metabolik profillerinde düzelmeler olduğunu bildirmektedir. PKOS ve İD tedavisi için a-lipoik asit (ALA) kullanımı da olası bir terapötik yaklaşım olarak kabul edilmektedir. ALA güçlü bir antioksidan olmanın yanı sıra insülinden bağımsız bir mekanizma ile glikoz taşıyıcı 4'ün (GLUT4) plazma zarına translokasyonunu indükleyen bir hücresel enerji sensörü olan 5'-adenosin monofosfatla aktive edilen protein kinazın (AMPK) aktivasyonu yoluyla insülin duyarlılığını artırabilir. Bu nedenle PKOS'lu kadınlarda ALA'nın oksidatif stresi azaltarak insülin duyarlılı̆̆ını ve üreme fonksiyonlarını artırabileceği ve metabolik anormallikleri düzeltebileceği belirtilmektedir. Son zamanlarda yapılan çalışmalarda ise inositol ve lipoik asidin ayrı ayrı takviyesine oranla kombine tedavi ile daha iyi sonuçlar alındığı bulunmuştur. Bu derlemede inositol ve ALA'nın ayrı ayrı ve ikisinin kombine tedavisinin PKOS'taki etkisi incelenmiştir.

Anahtar Sözcülkler: Polikistik over sendromu, İnositol, Lipoik asit, Terapötik ajan

\begin{abstract}
Polycystic ovary syndrome (PCOS) is an endocrine disorder seen in women of reproductive age and causes reproductive, hormonal and metabolic anomalies. Different therapeutic agents with insulin sensitizing properties are also used for the treatment of PCOS due to the accompany of insulin resistance (IR). Inositol with insulin sensitizing properties and alpha lipoic acid with antioxidant properties are among these therapeutic agents. Inositol (myo-inositol and di-chiroinositol) is a dietary supplement that plays a role in insulin signal transduction as a secondary messenger and has been shown to be effective in the treatment of PCOS. Studies have reported that ovulation rate, menstrual cycles and metabolic profiles in women with PCOS have improved with inositol supplementation. The use of a-lipoic acid (ALA) for the treatment of PCOS and IR is also considered a possible therapeutic approach. In addition to being a potent antioxidant, ALA can increase insulin sensitivity through activation of the 5'-adenosine monophosphate-activated protein kinase (AMPK), which is a cellular energy sensor that induces the translocation of glucose carrier 4 (GLUT4) into the plasma membrane through an insulin-independent mechanism. For this reason, it is stated that ALA can increase insulin sensitivity and reproductive functions and correct metabolic abnormalities in women with PCOS by reducing oxidative stress. In recent studies, it was found that better results were obtained with combined therapy compared to the individual supplementation of inositol and lipoic acid. In this review, the effects of inositol and ALA separately and the combined treatment of both in PCOS were investigated.
\end{abstract}

Keywords: Polycystic ovary syndrome, Inositol, Lipoic acid, Therapeutic agent 


\section{GíRiş}

Polikistik over sendromu (PKOS), üreme ve genel sağlık üzerine etkileri olan çok geniş kapsamlı bir kadın hastalı̆̆ıdır (1). PKOS, üreme çağındaki kadınlarda en sık görülen ve son zamanlarda kadınların $\% 6-20$ 'sini (kullanılan tanı kriterlerine ve populasyona bağlı olarak) etkilediği tahmin edilen heterojen bir endokrin bozukluktur (2-4). Stein ve Leventhal, 1935'te değişik derecelerde hirsutizm, kronik anovülasyon, bilateral over büyümesi ve obezite ile ilişkisi nedeniyle PKOS'u bir sendrom olarak tanımlamışlardır (5). PKOS'un asl nedeni bilinmemektedir ve muhtemelen genetik faktörler, doğum öncesi yüksek androjene maruz kalma, epigenetik ve çevresel faktörlerin bir kombinasyonundan kaynaklandığı düşünülmektedir. Bu sendromun ortaya çımasında ve tedavisinde yer alan çeşitli çevresel faktörler arasında diyet düzeni, fiziksel aktivite, sigara içme ve stres sayılabilir $(6,7)$.

Uluslararası kanıta dayalı bir kılavuzda PKOS'un değerlendirilmesi ve yönetimi için 2003 yllında Rotterdam'da ESHRE (European Society for Human Reproduction and Embryology)/ASRM (American Society for Reproductive Medicine)konferansında belirlenen tanı kriterlerinden yararlanılabileceği belirtilmektedir. PKOS teşhisi bu kriterlere göre yapıldığında aşağıda verilen parametrelerden iki tanesinin saptanması gerekmektedir $(1,8)$.

- Yumurtlama düzensizliği

- Klinik ve/veya biyokimyasal hiperandrojenizm

- Ultrasonda polikistik over morfolojisi

Bu sendrom kadınlarda neden olduğu endokrin bozuklukların yanı sıra birçok metabolik hastalık ile de ilişkilendirilmektedir. Bu nedenle PKOS tedavisi için farklı terapötik ajanlar da kullanılmaktadır. İnsülin duyarlaştırıcı özelliği bulunan inositol ve antioksidan özelliği olan alfa lipoik asit de bu terapötik ajanlar arasında yer almaktadır. İnositol (myo-inositol ve di-chiroinositol), ikincil bir haberci olarak insülin sinyal iletimi transdüksiyonunda rol alan ve PKOS tedavisinde etkili olduğu gösterilen bir besin takviyesidir (9). İnositol insülin, folikül uyarıcı hormon (FSH) ve tiroid uyarıcı hormon (TSH) gibi çeşitli reseptörlerin reseptör sonrası sinyal iletiminde yer alır. Myo-inositol (MI), inositolün en yaygın kullanılan izoformlarından biridir $(10,11)$. MI, insülin sinyal transdüksiyonunda yer alan bir membran fosfolipidi olan inositolfosfoglikan (IPG) içine dahil edilebilir. Reseptörünün insülin ile etkileşimi, inositollerin aracilık ettiği bu transdüksiyon yolunu aktive edebilir ve glikozun oksidatif olmayan metabolizma yerine oksidatif metabolizmaya dahil olmasını sağlayan hücre içi habercilerin oluşumunu sağlayabilir. MI-IPG, insülin direncini (ID) azaltabilir ve glikoz metabolizmasını geliştirebilir (12). Glikoz taşıyıcı 4'ün (GLUT4) hücrelere translokasyonunu düzenler ve adenilat siklaz enziminin modüle edilmesiyle serbest yağ asitlerinin salınımını aşağı yönde regüle eder (13). Normalde MI, insülin tarafindan uyarılan bir epimeraz ile enzimatik olarak başka bir önemli inositol olan D-chiro-inositol'e (DCI) dönüştürülür (14). İ'si olan PKOS'lu kadınlarda epimeraz aktivitesi düzensizdir ve hem plazma hem de periferal dokularda bu iki izomerin normal dengesinin değişmesine neden olur (15). Sonuç olarak, PKOS hastalarında değişen inositol dengesi hem ID hem de üreme problemlerine neden olabilir (15-17). Yapılan sistematik derlemelerde, PKOS'lu kadınlarda yumurtlama hızı ve adet döngülerinde inositol takviyesi ile düzelmeler olabileceği belirtilmiştir $(9,18)$. Ayrıca, bazı veriler inositolün gestasyonel diyabet riskini azaltmada etkili olabileceğini göstermektedir (19).

Son zamanlarda PKOS ve ID tedavisi için a-lipoik asit (ALA) kullanımı da olası bir terapötik yaklaşım olarak kabul edilmiştir (20, 21). ALA ve indirgenmiş formu olan dihidrolipoik asit (DHLA), reaktif oksijen türlerini (ROS) etkisizleştiren ve diğer antioksidan molekülleri yeniden üretebilen güçlü antioksidan moleküllerdir. Dahası, ALA, NF-кB'nin (nuclear factor kappa-light-chain-enhancer of activated Bcells) aracılık ettiği inflamatuar paternin bir inhibitörüdür ve ayrıca immünomodülatör fonksiyona sahiptir (22). ALA metabolizmada insülinden bağımsız bir mekanizma ile GLUT4'ün plazma zarına translokasyonunu indükleyen bir hücresel enerji sensörü olan AMPK aktivasyonu yoluyla insülin duyarlılığını artırabilir (23-25). ALA’nın güçlü bir antioksidan olduğu ve tip 2 diyabet hastalarında glikoz kontrolünü geliştirdiği, oksidatif stres ve ID'yi azaltma etkileri bildirilmiştir. Bu nedenle PKOS'lu kadınlarda ALA'nın oksidatif stresi azaltarak insülin duyarlılığını ve üreme fonksiyonlarını artırabileceği ve metabolik anormallikleri düzeltebileceği belirtilmektedir (26).

Literatür, PKOS ile ilişkili metabolik anormallikleri düzeltebilecek birer terapötik ajan olan inositol ve ALA kullanımını desteklemektedir. Bu konudaki klinik araştırmaların desteklenmesi ve bu terapötik ajanlara dikkat çekmek amacıyla bu derlemeye ihtiyaç duyulmuştur.

$\mathrm{Bu}$ derlemede, inositol ve alfa lipoik asidin PKOS patofizyolojisinde yer alabileceği muhtemel mekanizmalar ile birlikte, inositol ve lipoik asit takviyesinin PKOS tedavisinde hormonal ve metabolik göstergeler üzerindeki etkileri değerlendirilerek kullanımlarının ve etkinliklerinin incelenmesi amaçlanmıştır.

İnositol ve lipoik asidin PKOS ile ilişkisini araştırmak amaciyla PubMed, Google Akademik, Science Direct ve Web Of Science veri tabanlarında "inositol", "D-chiroinositol", "myo-inositol", "lipoik asit" ve "pkos" anahtar kelimeleri Türkçe ve İngilizce olarak taranarak erişime açık klinik çalışmalar ve derleme makaleler değerlendirilmiştir. 
İnositol ve lipoik asidin PKOS ile ilişkisini değerlendirmek için "ve/and" kelimeleri kullanılmıştır.

\section{POLIKISTIK OVER SENDROMU}

Hirsutizm, akne ve/veya alopesi, menstrüel düzensizlik, anovülasyon ve kısırlı gibi hiperandrojenik semptomlar ile birlikte artmış over ve adrenal androjen salgılanması ile karakterize olan PKOS heterojen bir sendromdur (27). Bu sendromda gözlenen endokrinolojik anormalliklerin yanı sıra, uzun dönemde ID, hiperinsülinemi, merkezi obezite ve metabolik sendrom (MeTS), tip 2 diyabet, kardiyovasküler hastalıklar, hipertansiyon, ateroskleroz ve dislipidemi gibi sağlık sorunlarına da temel oluşturur. Hiperinsülinemi ve ID, yumurtalık androjen üretimini uyarır ve serum seks hormonu bağlayıcı globulin (SHBG) konsantrasyonlarını azaltır, dolaşımdaki serbest testosteron seviyelerinin artmasına neden olur. ID ile yumurtalı hiperandrojenizmi arasındaki bu ilişki insülinin doğrudan yumurtalık fonksiyonunu etkilediğini göstermektedir (28). Ayrıca PKOS'lu kadınlarda gestasyonel diyabet ve preterm doğum gibi doğumsal komplikasyonlar da ortaya çıkabilir (29).

Hastanın genel görünümü ve beden kütle indeksi (BKI), PKOS dahil sistemik ve endokrin problemleri hakkında ipuçları verebilir (3). PKOS'lu kadınların yaklaşık \%4050'si aşırı kiloludur. Karın bölgesindeki yağlanmanın ve bel-kalça çevresinin artması, ID ile birlikte azalmış menstrüasyon sıklı̆̆ı ve subfertilite ile ilişkilidir (30). Obezite; periferde androjenlerin östrojenlere dönüşümünde artı̧, serbest estradiol ile testosteron düzeylerinin artmasina neden olan SHBG düzeylerinde azalma ve over stromasinda androjen sentezini uyaran insülin seviyesindeki artış yoluyla ovulasyon sorunlarına neden olmaktadır. Başlangıçtaki ağırlı̆ın \%5’inden fazlasının kaybedilmesi ile ortaya çıkan bu değişiklikler düzelebilmektedir (31).

İnsülin direnci, merkezi obezite ve dislipideminin varlığı PKOS'lu kadınları diyabet ve kardiyovasküler hastalık gelişimi açısından daha yüksek risk altında bırakmaktadır. Obez kadınlar ve ayrıca PKOS'lu birçok zayıf kadın, ID'ye ve artmış serum insülin konsantrasyonlarına sahip olabilmektedir. PKOS'lu hem obez hem de obez olmayan kadınların, normal yumurtalıkları olan yaş ve ağırlık bakımından eşleştirilmiş kadınlardan insüline direnci açısından daha fazla risk altında olduğu belirtilmektedir. Bu nedenle, PKOS'lu kadınlarda ID'yi destekleyen ve obeziteden bağımsız faktörler olduğu görülmektedir. Oligosomenorik olan PKOS'lu kadınlarm BKİ'si ne olursa olsun, düzenli döngüleri olanlara göre insüline dirençli olma olasılı̆̆ı daha yüksektir. İnsülin direnci; BKİ ne olursa olsun ortaya çıssa da, PKOS ve obezitenin ortak birlikteliği glikoz homeostazı üzerinde sinerjik zararlı bir etkiye sahiptir ve hem hiperandrojenizmi hem de anovülasyonu kötüleştirebilir (32, 33). Birçok çalışmada PKOS'lu hastalarda \%5 ila10 oranında- ki ağırlık kaybının kardiyovasküler hastalık, tip 2 diyabet, endokrin ve üreme parametreleri riskini azaltmada olumlu etkileri olduğu bildirilmiştir (34-36). Ağırlık kaybedebilmek için geliştirilen strateji 500-1000 kcal/gün kalori kısıtlaması ile birlikte düzenli fiziksel aktivite, stresi azaltan davranışsal, psikolojik terapi ve sosyal destekle sağlanabilir (37).

Obez olsun veya olmasın PKOS'lu kadınlar genellikle, sendromun ortak özellikleri olan ID ve hiperinsülinemi nedeniyle insülin duyarlaştırıcı maddelerle tedavi edilir. PKOS'lu kadınlarda ID'nin tedavisinde metformine bağlı hafif gastrointestinal yan etkiler ve glitazonlarla ilgili daha ciddi yan etkiler, diğer tıbbi tedavi seçeneklerinin incelenmesi ihtiyacını doğurmuştur.

\section{INOSITOLLERIN POLIKISTIK OVER SENDROMUNDA ROLLERI}

İnositol (sikloheksan-1, 2, 3, 4, 5, 6-heksol), bir poliol olup dokuz farklı stereoizomerik formu vardır $(11,38)$. İnositol'ün en yaygın iki stereoizomeri MI ve DCI‘dır (39).

Bir siklitol olan MI serbest formda veya fosfolipidlerden inositolfosfat türevlerinin bağlı bileşeni olarak hayvan ve bitki hücrelerinde doğal olarak bulunur. Gida maddeleri de dahil olmak üzere doğada bulunan inositolün baskın izomerik formu MI'dır. Daha önce MI'nın B vitamini ailesine ait olduğu düşünülürken insan vücudunda D-glikozdan yeterli miktarda üretildiği saptandığından esansiyel bir besin maddesi olarak sayılmamaktadır (40). Tüm canlı hücrelerin membranları inositolfosfolipidler içerir; birçok bitki dokusunda başlıca fosfor depolama şekli fitik asittir. İnositol içeren fosfolipid ya da fitik asit gibi serbest formda MI, bitkisel ve hayvansal kaynaklı diyette yer almaktadır. MI doğal olarak karaciğer ve böbrekte sentezlenir; ama insanlar tahıl, meyve, sebze ve et gibi diyetsel kaynaklardan da MI alırlar (11, 38, 41). MI en çok taze meyve ve sebzelerde bulunmakla birlikte bezelye, fasulye, tahıl ve findıkta bulunur (42). MI; hücre zarı oluşumu, lipid sentezi, hücre büyümesi ve çeşitli sistemik işlemlerde ve plazma habercilerinde ikinci habercilerin öncüsü olarak sinyal iletim mekanizmaları ile ilgili hücre morfogenezi ve sitogenezinde önemli rol oynar (43).

\section{Ínositoller ve Polikistik Over Sendromunda Metabolik Anormallikler}

Yağ dokusu, kas ve karaciğerde MI ve DCI arasındaki bulunma oranlarında belirgin farklar olduğu görülmüştür. $\mathrm{Bu}$ oran, iki izomerin bu dokularda oynayabileceği farklı işlevleri yansıtmaktadır (44). İki molekülün farklı dokulardaki dengeli bulunma oranı doku fonksiyonlarının düzenli çalışması için çok önemli olduğundan, MI ve DCI'nın fizyolojik oranla ilişkisine dayanan bir tedavinin en uygun yöntem olduğu öne sürülmektedir. Son zamanlarda yapılan iki çalışmada, MI+DCI içeren kombine tedavi ile fizyolojik 
plazma oranının 40:1 olduğunu gösterilmiştir (45). Ayrıca, MI'ye karşı DCI oranları aktif olarak korunur, çünkü MI doku ihtiyacına bağlı olarak nikotinamid adenin dinükleotite (NAD-NADH'ye) bağlı bir epimeraz yoluyla enzimatik olarak DCI'ya dönüştürülür. Yapılan farklı çalışmalarda her iki inositol türevinin de ID'nin yanında dislipidemiyi de iyileştirdiği bulunmuştur (10, 46-49). Başka bir çalışmada; 47 PKOS'lu hastaya sadece folik asit (FA) (400 $\mu \mathrm{g}$ /gün), 45'inin ise MI ve FA (4 mg/gün MI+400 $\mu \mathrm{g} /$ gün FA) kombine tedaviyi dört ay süreyle alması sağlanmıştır. Kombine tedavi alan grupta ağırlık kaybı ile birlikte leptin seviyelerinde de anlamlı azalma gözlenmiştir. Aynı zamanda kombine tedavi alan grupta HDL kolesterol düzeyinde anlamlı bir artış sağlanması PKOS'un uzun dönem sonuçlarından biri olan kardiyovasküler risk semptomlarını iyileştirdiğini göstermektedir (50). Farelerde, myo-inositol takviyesi ile postprandiyal glikoz \%10 oranında azaltılmış, muhtemelen leptinde bir düşüşe bağlı olarak intra-abdominal adipozitede bir azalma saptanmıştır (51).

\section{İnositollerin Karbonhidrat Metabolizması Üzerine Etkisi}

Epimeraz aktivite düzensizliği MI/DCI oranını etkiler; insülin ve FSH gibi hormon sinyallerini bozabilir. Literatür bulguları, PKOS'lu kadınların MI ve/veya DCI'nın doku miktarında ve/veya kullanımında bir anomali olduğunu göstermektedir. Bu durum muhtemelen sendromun tipik özelliği olan ID'nin oluşmasında rol oynar $(14,52)$, ayrıca iki ana stereoizomerinin insülin sinyalleşmesinde ayrı rol oynadığını düşündürür. DCI esas olarak glikojen sentezinde (karaciğer, yağ ve kas) rol alırken MI, glikoz taşıyıcıların aktivasyonundan ve glikoz kullanımından sorumludur (14). İnsülin alıcısına bağlandığında, MI veya DCI (DCI-IPG ve MI-IPG) içeren iki ayrı IPG hücre zarının dış tarafinda bulunan glikosilfosfatidilinositol lipidlerin hidrolizi ile salınır. IPG'ler hücre içi metabolik süreçleri, yani glikozun oksidatif ve oksidatif olmayan metabolizmasinı kontrol eden anahtar enzimleri aktive ederek etkilerler (53). İnositolglikanlar, insülin ile uyarıldıktan sonra insüline duyarlı hücrelerden salınan küçük oligosakaritlerdir. İzole edilmiş IPG'ler, insüline duyarlı hücreleri aktive edebilir. IPG'lere dahil edilen hem DCI hem de MI bazı farklılıklara dikkat edilmesine rağmen İD'yi önemli ölçüde azaltır ve uygun bir glikoz metabolizmasının oluşmasında rol oynar (44). Başta ID ve diyabet komplikasyonları olmak üzere, MI ve DCI'nın metabolizmalarındaki hücresel işlev bozuklukları ve anormallikler bir takım hastalık durumlarının gelişmesinde rol oynar (39). Yapılan farklı çalışmalarda PKOS'lu kadınlarda MI takviyesinin, insülin duyarlılı̆̆ında ve ovülasyon işlevinde düzelme sağladığı bulunmuştur $(47,54,55)$. Başka bir çalışmada da, inositolün (MI veya DCI izoformlarında) PKOS'lu genç kadınlarda insülin duyarlılığını ve ovülasyon fonksiyonu iyileştirdiği saptanmıştır (39). Bir çalışmada, 20 obez PKOS'lu kadında 24 haftalık takviyeden sonra insülin direnci indeksinin (HOMA-IR) yanı sıra LDL-kolesterol ve insülin seviyelerinde bir düşüş olduğu gösterilmiştir (48). Diğer bir çalışmada ise PKOS'lu (BKI $\left.>27 \mathrm{~kg} / \mathrm{m}^{2}\right) 50$ kadında altı ay süreyle sadece MI takviyesi alan grubun klinik sonuçları kombine tedavi (MI+DGI) alan grubunki ile karşlaştırılmıştır. Kombine tedavi alan kadınlar diğer grup ile karşılaştırıldığında glikoz metabolizmasının daha hızlı bir şekilde normalleştiği görülmüştür (49).

Yapılan bir çalışmada PKOS'lu hastalarda ID'nin tedavisinde kullanılan metforminin ve MI'nın etkinliğini araştırılmış; 12 hasta $1.500 \mathrm{mg}$ /gün oral metformin tedavisi alırken 60 hasta $4 \mathrm{~g}$ inositol $+400 \mu \mathrm{g}$ FA $(\mathrm{n}=60)$ ile tedavi edilmiştir. Metformin tedavisi alan hastalarda gebelik oranı \%36,6 iken, MI ve FA alan hastalarda bu oran \% 48,4 olarak belirlenmiştir $(\mathrm{p}=0,09)(56)$.

\section{İnositollerin Polikistik Over Sendromunda Over Fonksiyonları ve İnfertilite Üzerine Etkisi}

MI-fosfatın gonadotropin salgilatıcı hormon $(\mathrm{GnRH})$ agonist aracılı LH inhibisyonunda gerekli olduğu göz önüne alındığında, artan MI-fosfat miktarının LH modülasyonunda rol oynayabileceği varsayılabilir. Oosit aktivasyonunda en önemli olay hücre içi $\mathrm{Ca}^{+2}$ konsantrasyonundaki geçici artıştır. $\mathrm{Ca}^{+2}$ artışı olmaması aktivasyonu önlediği için infertiliteye sebep olabilmektedir. İnositolfosfat3 (IP3), mitokondriden hücre içi kalsiyum $\left(\mathrm{Ca}^{+2}\right)$ salınımının düzenlenmesinde işbirliği yapar. Oositlerde, bu mekanizma oosit matrisinde spesifik bir reseptör alt tipini (IP3-R1) içerir ve kalsiyum dalgalanmalarına oosit duyarlılığının maksimum değerine ulaştı̆̆ında yani oogenezin son aşamalarındaki oosit olgunlaşmasında önemli bir rol oynadığı düşünülmektedir (44). Yapılan bir çalışmada faredeki oosit olgunlaşmasının IP3 enjeksiyonundan sonra kalsiyum salınımı ile tetiklendiği bulunmuştur (57). Dahası, MI ile oosit kültür takviyesi, döllenme-yetkin yumurtalara mayotik ilerlemeyi teşvik ederken, hücre içi MI depolarının tükenmesi inositol ile ilişkili yolakları duyarsızlaştırı, IP3 ve kalsiyum salımını azaltır (58). İn vitro bir çalışma MI'nin embriyo kalitesini ve performansını da arttırdığını kanıtlamıştır (59). PKOS'lu kadınlarda MI'nın oosit kalitesi üzerine etkilerini değerlendirmek amacıyla yapılan çalışmalarda hastalar iki gruba ayrılarak bir grubun MI ve FA tedavisi diğer grubun ise sadece FA alması sağlanmış; kombine tedavi alan alan gruptaki kadınların oosit kalitesinin daha iyi olduğu bulunmuştur $(50,60)$. Başka bir çalışmada ise inositolün iki farklı izomerinin etkisini incelemek amaciyla in vitro fertilizasyon (IVF) tedavisi alan PKOS'lu hastalar iki gruba ayrılmıştır. Birinci gruptaki hastalara MI $(1,1 \mathrm{~g})$ ve DCI $(27,6 \mathrm{mg})$; ikinci gruptaki hastalara ise yalnızca DCI $(500 \mathrm{mg})$ verilmiştir. Veriler iki izomerin birlikte verilmesinin oosit kalitesi üzerine daha etkili olduğunu göstermektedir (61). IVF tedavisi 
alan 60 PKOS'lu kadında 12 hafta boyunca MI (550 mg) ile birlikte verilen iki farklı doz DCI'nın (150 mg ve 13,8 $\mathrm{mg}$ ) etkisininin değerlendirildiği çalışmada MI-DCI'nin yüksek doz kombinasyonunun gebelik oranlarını artırdığı ve yumurtalık hiperstimülasyon sendromu riskini azaltabileceği bulunmuştur (62).

Doza bağlı etkinin değerlendirildiği bir çalışmada DCI'nın ovülasyon üzerine etkisi hastalara önce iki ay boyunca FSH tedavisi uygulanarak daha sonra plasebo veya dört farklı miktarda (300-600-1.200-2.400 mg/gün) DCI verilerek incelenmiştir. Sonuçlar 600, 1.200 ve $2.400 \mathrm{mg}$ DCI ile tedavi edilen hastalarda embriyo kalitesinin diğer gruptan önemli ölçüde düşük olduğunu ve yüksek doz DCI tedavisinin yararlı etkileri olmadığını göstermektedir (63).

Myo-inositol tedavisinin PKOS'lu kadınları etkileyen hormon dengesi, düzensiz adet döngüsü, anovülasyon ve kısırlık gibi üreme morbiditelerini iyileştirdiği gösterilmiştir. Özellikle MI, androjen seviyelerini (testosteron ve androstenedion) azaltabilir, luteinleştici hormon (LH)/ FSH oranın düzeltir ve luteal fazda yeterli progesteron üretimini sağlayarak yumurtlamayı indükler (45). PKOS'lu kadınlarda MI tedavisinin hormonal parametreler üzerine etkilerinin değerlendirildiği bir çalışmada 50 obez birey iki gruba ayrılarak; birinci gruba üç ay boyunca MI (2 $\mathrm{g}$ /gün inositol) ve FA (200 mg/gün) verilirken, ikinci gruba sadece FA (200 mg/gün) verilmiştir. MI alan grupta diğer gruba göre plazma insülin ve LH/FSH düzeyinin daha düşük olduğu ve menstrüel siklusta da iyileşme olduğu belirlenmiştir (64). PKOS'lu hastalarda yardımcı üreme teknolojisi (ART) döngüleri sırasında MI uygulamasının oosit kalitesi, fertilizasyon hızı ve embriyo kalitesi üzerindeki etkisini değerlendirmek amacıyla 50 infertil PKOS hastası rastgele iki gruba ayrıldığı araştırmada çalışma grubuna, 400 mg FA ile kombine günlük $4 \mathrm{~g} \mathrm{MI}$; kontrol grubuna ise antagonist döngüsüne başlamadan önce ovumun alındığı güne kadar sadece 400 mg FA verilmiştir. Granulosa hücrelerinde oosit kalitesinin bir faktörü olarak PGK1, RGS2 ve CDC42'nin gen ekspresyonu, toplam antioksidan kapasite (TAC) ve ROS seviyeleri foliküler sıvıda değerlendirilmiştir. Çalışma grubunda metafaz II oosit, döllenme oranı ve embriyo kalitesi yüzdesi anlamlı olarak düzeldiği ( $p<0.05)$, ancak alınan oosit sayısı ve folikül sayısı açısından gruplar arasında istatistiksel olarak bir fark bulunmamıştır. Ayrıca PGK1, RGS2 ve CDC42'nin gen ekspresyonu çalışma grubunda anlamlı olarak daha yüksek iken iki grup arasında TAG ve ROS düzeyleri açısından fark bulunmamıştır. Bu çalışmanın bulguları, MI'nın granüloza hücrelerinde gen ekspresyonunu değiştirdiğini ve ART geçiren PKOS hastalarında oosit ve embriyo kalitesini artırdığını göstermektedir (65).

PKOS'lu hastalarda inositolün etkileri aşağıda özetlenmektedir (66):
- İnsülin duyarlılığında iyileştirme sağlamak,

- Spontan ovülasyonda artış sağlamak,

- Spontan gebeliklerde artış sağlamak,

- Âdet döngüsünün düzenlenmesine yardımcı olmak,

- Fertilite tedavileri için gerekli FSH dozunun düşürülmesine yardımcı olmak,

- Olgun oositlerin sayısında artış sağlamak,

- Embriyo kalitesinin iyileştirilmesini sağlamak,

- Lipit profilinde iyileşme sağlamaktır.

\section{ALFA LIPOİK ASIDIN POLIKISTIK OVER SENDROMUNDAKI ROLÜ}

Alfa lipoik asit (ALA) veya 6,8-ditiyoktanoik asit [Uluslararası Saf ve Uygulamalı Kimya Birliği (IUPAC) adı (R)-5(1,2-ditiyolan-3-il) pentanoik asit] olarak bilinen lipoik asit (LA) birçok hücresel redoks reaksiyonları için esansiyel bir kofaktördür. Hidrofobik kofaktör ALA, halka şeklinde bir intramoleküler disülfür bağı, sülfür bağlı bir substrat ile bir ara form ve iki sülfhidril içeren indirgenmiş oksitlenmiş bir formda görünür (67). Molekül içindeki disülfit bağı, mitokondriyal 2-ketoasit dehidrojenazlar tarafindan kataliz için gerekli olan ve bu multienzim komplekslerinin stabilizasyonuna ve redoks dengesinin düzenlemesine katılan bir indirgeyici potansiyel kaynağı sağlar. Bu fonksiyonlar ALA'yı hücre büyümesi, karbonhidratların oksidasyonu, amino asitler, diğer yakıtlar ve mitokondriyal redoks dengesinin düzenlenmesi için zorunlu kılar (68).

Alfa lipoik asidin iki enantiyomeri bulunur ve her iki formun da farklı işlevleri vardır. ALA glisin molekülünün sentezi ve parçalanmasında rol oynayan dört önemli proteinin mitokondriyal kompleksinin önemli bir bileşenidir. ALA aynı zamanda, glikoz metabolizması ve enerji üretimine katılan iki mitokondriyal enzim olan piruvat dehidrojenaz kompleksi ve a-ketoglutarat dehidrogenaz kompleksi dahil olmak üzere birçok enzim için bir kofaktördür (69).

İnsanlar ALA'yı karaciğerde ve diğer dokularda de novo olarak çok az miktarda yağ asitlerinden ve sisteinden sentezleyebilir. Bu nedenle ALA'nın ekzojen kaynaklardan alınması gerekir. Diyetsel ALA, hem hayvansal hem de bitkisel kaynaklardan alınır. ALA öncelikle kırmızı et, karaciğer, kalp ve böbrek gibi hayvansal kaynaklı besinlerde bulunur. ALA'nın en bol bulunduğu bitkisel kaynaklar ise brokoli, domates, brüksel lahanası, patates, bezelye, pirinç kepeği ve ıspanaktır. Ayrıca, yemekle birlikte alımın ALA'nın biyolojik kullanılabilirliğini azalttığı da öne sürülmüştür. Bu nedenle, ALA'nın yemekten 30 dakika önce veya iki saat sonra alınması önerilmektedir. Tek doz tabletler halinde (50 ila $600 \mathrm{mg}$ ) alınan ALA, 30 dakika ila bir saat sonra tamamen emilir (70). 
Alfa lipoik asit, benzersiz bir endojen ve eksojen antioksidandır, çünkü oksitlenmiş ve indirgenmiş formunda doğrudan ROS'ları nötralize edebilir. ALA hem suda hem de yağda çözünür; bu nedenle hidrofilik olan $\mathrm{C}$ vitamini ve hidrofobik olan E vitaminin aksine antioksidan etkisi sitozolde olduğu gibi, plazma zarında, serum ve lipoproteinlerde de meydana gelir. ALA; hidroksil radikallerini, hipokloröz asit ve oksijen singletlerini temizleyebilir (70). Bu özelliğinin yanında antioksidan sistemleri aktive edebilir ve ayrıca inflamatuar belirteçleri etkileyebilir (71). Metabolik süreçlerdeki rolünün yanı sıra, ALA metabolik bozuklukları, nöron dejenerasyonunu, romatoidartriti, diyabetik polinöropatiyi ve vücut ağırlığını iyileştirebilir (20). ALA, hipotalamik AMP ile AMPK bastırma ve diyet enerjisi alımını azaltma yoluyla vücut ağırlığını ve yağ kütlesi kaybını destekleyebilir; lipoprotein lipaz aktivitesini azaltır, enerji tüketimini, lipoliz ve insülin duyarlılığını artırır ve lipogenezi inhibe eder (72). Ayrıca, klinik çalışmalar ALA'nın güvenli olduğunu ve henüz ciddi bir yan etki bildirilmediğini ortaya koymuştur $(73,74)$. Genazzani ve arkadaşları tarafindan yapılan bir çalışmada obez PKOS hastalarında ALA uygulamasının hormonal ve metabolik parametreler üzerindeki etkinliğini değerlendirmek amacıyla 32 PKOS hastasına günlük 400 mg ALA takviyesi yapılmıştır. 12 haftalık uygulama öncesi ve sonrasında yapılan değerlendirmede insülin, glikoz, BKİ ve HOMA-IR değerinin anlamlı derecede düştüğü bulunmuş; ancak üreme parametreleri ile ilgili herhangi bir değişiklik saptanmamıştır. ALA uygulaması, özellikle ailede diyabet öyküsü olan hastalarda insülin duyarlılığını arttırmıştır. Trigliserit plazma seviyelerinin azalmasının, bu hastalarda karaciğer fonksiyonlarını büyük ölçüde iyileştirdiği ve/veya koruduğunu, karaciğer yetmezliği gelişme riskini azaltabileceği değerlendirilmesi yapılmıştır (75).

\section{Alfa Lipoik Asidin Karbonhidrat Metabolizması Üzerine Etkisi}

Diyabet; kalp yetmezliği, miyokard enfarktüsü, nöropatik ağrı ve felce yol açabilen ateroskleroz ve hipertansiyon gelişimi için önemli bir faktördür (76). Hiperglisemi, mitokondride serbest oksijen radikallerinin aşırı üretimi ile bağlantılı olan oksidatif strese yol açar, bu da hücre içi yolakları harekete geçirerek (örn: protein kinaz $\mathrm{G}$ ve heksosamin yolakları) nöronal ve endotel hasara neden olur (77).

Alfa lipoik asidin hem insüline dirençli hem de insüline duyarlı kas dokularında glikoz alımını arttırdığı gösterilmiştir $(78,79)$. Hayvan modelinde ALA'nın, iskelet kaslarında AMPK'yı artırma yoluyla GLUT-4'ü arttırdığı böylece glikoz kullanımını modüle ettiği ve arttırdığı gösterilmiştir (23, 24). ALA, glikoz kullanımını arttırdığı ve glisemik kontrolü geliştirdiği için karaciğerde meydana gelen detoksifikasyon mekanizmalarında kilit rol oynar. Bununla birlikte, hayvan diyabet modellerinde, ALA takviyesinin nöral kan akışını ve sinir iletimini iyileştirdiği bildirilmiştir (70). Bir pleiot- ropik bileşik olan ALA son zamanlarda, diyabet ve PCOS gibi dismetabolik kaynaklı diğer endokrin hastalıkların tedavisinde potansiyel terapötik ajan olarak önerilmiştir (80, 81). ALA; GLUT1 ve GLUT4 glikoz taşıyıcılarının hücre içinde yeniden dağıtılmasıyla glikoz alımını uyararak glikoz ve lipid metabolizmasının düzenlenmesinde rol oynar (82). Bunun yanında ALA'nın, PKOS'dan etkilenen kadınlarda üreme fonksiyonunu ve metabolik parametreleri iyileştirebileceği belirtilmektedir. Masharani ve arkadaşları PKOS'lu altı zayıf kadında, 16 hafta boyunca günde iki kez 600 mg'lık ALA takviyesinin bu hasta grubunda şiddetli ID olmamasına rağmen, trigliserit seviyelerinin düşmesini sağladığı, insülin duyarlılığında ve adet sıklığında düzelme sağladığı göstermişlerdir (83).

\section{Alfa Lipoik Asit ve İnositollerin Kombine Tedavisinin Polikistik Over Sendromundaki Etkileri}

Yapılan farklı çalışmalarda PKOS'lu kadınlarda MI ve ALA'nın kombine takviyesinin etkileri de incelenmiştir. Uzun süreli (24 ay boyunca) MI-ALA(2000mg+800mg) kombine diyet takviyesinin yapıldığı PKOS'lu hastalarda insülin duyarlılığının arttığı ve menstrüal döngünün normalleştiği bulunmuştur (84). Genazzani ve arkadaşları tarafindan yapılan bir çalışmada, 34 obez PKOS hastasinda ID'nin ve glikoz yükünün neden olduğu hiperinsülineminin azaltılmasında 12 haftalık $400 \mathrm{mg}$ ALA ve 1 g MI kombinasyonunun, gonadotropin salgilanmasinı iyileştiren etkinliği değerlendirilmiştir. LH serum seviyelerinde ve LH/FSH oranlarında belirgin bir azalma olmasına rağmen, sadece hiperinsulinemik PKOS hastalarında HOMA-IR ve oral glukoz tolerans testine (OGTT) verilen cevapta, insülin duyarlılığında anlamlı bir artış olduğunu gösteren değişiklikler görülmüştür. BKI'de anlamlı olmayan bir azalma saptanmıştır (85). PKOS'lu kadınlarda $1.7 \mathrm{~g}$ metformin ile yapılan tedaviye ALA ve MI eklenmesi, tek başına üç g metformin verilmesi ile yapılan karşılaştırmada hiperandrojenizm, BKİ ve HOMA-IR değerleri açısından daha iyi sonuçlar alındığı gösterilmiştir (86). Rago ve arkadaşları tarafindan daha önce IVF yapılan normal BKI olan PKOS hastalarında kombine MI ve ALA (2 g+800 mg) uygulamasının etkinliğini yalnız MI uygulaması etkinliği ile karşılaştırmak amacıyla PKOS'lu 65 hasta ile yaptıkları çalışmada kombine tedavi sonrasında insülin seviyeleri, BKİ ve yumurtalık hacminin önemli ölçüde azaldığı bulunmuştur. İki farklı tedavi arasında döllenme ve ayrilma oraninda veya ortalama transfer edilen embriyo sayısında ve klinik gebelikte bir fark bulunamamıştır. Bu veriler IVF yapılan PKOS hastalarında MI ve ALA takviyesinin uzun süreli kullanımının, üreme sonuçlarını ve metabolik profillerini iyileştirmeye yardımcı olabileceğini göstermektedir (87). Retrospektif gözlemsel bir çalışmada, IVF uygulanan, diyabetik akrabaları olan/olmayan, 
aşırı kilolu/obez PKOS hastalarına 500 mg DCI ve 300 mg ALA tedavisi uygulanmışır. Diyabetik akrabaları olan grupta daha düşük dozda gonadotropin, daha kısa stimülasyon günleri, daha fazla sayıda MII oosit ve daha fazla döllenmiş oosit görülme eğilimi olduğu bulunmuştur (88). Başka bir çalışmada, PKOS'lu İD'ye sahip 30 genç kadın, ya 6 altı ay süreyle $1 \mathrm{~g}$ MI, $5 \mathrm{mg}$ monokolin K ve $400 \mathrm{mg}$ ALA ile ya da $2 \mathrm{~g}$ MI, $10 \mathrm{mg}$ monokolin K, $800 \mathrm{mg}$ ALA ile tedavi edilmiştir. Doğal bir statin olan monokolin K, MI ve ALA ile yapilan kombine tedavinin; BKİ, dislipidemi, hirsutizm ve menstrüel bozukluklar gibi hiperandrojenizm ile ilişkili semptomlarda doza bağlı bir iyileşme gösterdiği bulunmuştur (89). PKOS'lu üreme çağındaki 46 kadın ile yapılan çalışmada (26 tedavi ve 20 kontrol); altı ay boyunca günde $1 \mathrm{~g}$ DCI ve $600 \mathrm{mg}$ ALA kombinasyonu verilen tedavi grubunda klinik ve metabolik özellikler açısından kontrol grubuna göre anlamlı düzelmeler olduğu bulunmuştur (90). Retrospektif olarak yapılan bir çalışmada, ALA'nın iki farklı dozda MI ile tedavisinin PKOS'lu kadınların klinik ve metabolik özellikleri üzerindeki etkilerini değerlendirmek amacıyla 71 kadın günde 800 mg ALA ile tedavi edilmiş: bu hastaların 43'ünün günde ek olarak $2000 \mathrm{mg}$ MI ve 28'inin ise $1000 \mathrm{mg}$ MI alması sağlanmıştır. Kadınların \% 71,2'sinde menstrüal döngü iyileşmiştir. Yüksek doz MI alan kadınların \%85.7'si, düşük doz MI alanların ise \%50'si menstrüal düzenliliği olduğunu bildirmiştir. PKOS'lu kadınların, metabolik fenotiplerine bakılmaksızın ALA + MI ile kombine tedavilerinde, daha yüksek MI alan hastalarda menstrüel döngü daha belirgin olarak olumlu yönde etkilenmiştir (12). HMGBl'in(High-mobility-groupbox-1), yumurtalıktaki azalmış CFTR (cystic-fibrosistransmembrane-conductance-regulator) ekspresyonunun bir sonucu olarak PKOS hastalarında arttığı ve insülin direnci ile ilişkili olduğu gösterilmiştir. İlk 3 ay boyunca günde iki kez, sonraki 3 ay günde bir kez olacak şekilde $400 \mathrm{mg}$ ALA ve $1000 \mathrm{mg}$ MI tedavisi uygulanan PKOS'lu ergenlerde HMGB l’in, çalışma grubunda kontrol grubuna kıyasla arttı̆̆ı ve tedaviden sonra normalleştiği görülmüştür. Tedavi ile insülin, HOMA-IR ve 17-hidroksiprogesteron önemli ölçüde azaldığı, kolesterol, LH, 17b-estradiol, delta 4-androstenedion ve testosteronun değişmediği bulunmuştur (91). Tablo I'de tek başına veya kombine tedavi olarak

Tablo I: PKOS'lu kadınlarda MI, DCI ve/veya ALA takviyesinin değerlendirilmesine yönelik yapılan bazı çalışmalar.

\begin{tabular}{|c|c|c|c|c|c|}
\hline Yazar/kaynak & Yil & $\begin{array}{l}\text { Hastalik/ } \\
\text { durum }\end{array}$ & $\begin{array}{c}\text { Örneklem } \\
\text { grubu }\end{array}$ & $\begin{array}{l}\text { Uygulama } \\
\text { protokolü }\end{array}$ & Sonuçlar \\
\hline $\begin{array}{l}\text { Genazzani ve ark. } \\
(47)\end{array}$ & 2008 & $\begin{array}{l}\text { PKOS'lu şişman } \\
\text { ve obez kadınlar }\end{array}$ & $\begin{array}{c}\text { Kontrol }=10 \\
\text { Müdahale }=10\end{array}$ & $\begin{array}{l}12 \text { hafta boyunca } \\
\text { günlük } 2 \mathrm{~g} \text { MI } \\
\text { Kontrol grubuna } \\
\text { FA }\end{array}$ & $\begin{array}{c}\text { LH, PRL, testosteron, insülin } \\
\text { konsantrasyonları ve LH/FSH, } \\
\text { glikoz yüküne insülin cevabı anlamlı } \\
\text { derecede azalma } \\
\text { HOMA-IR anlamlı derecede azalma } \\
\text { BKİde değişiklik yok. } \\
\text { Tüm PKOS hastalarında adet } \\
\text { döngüsü yeniden gelişme }\end{array}$ \\
\hline $\begin{array}{l}\text { Masharani ve ark. } \\
\text { (83) }\end{array}$ & 2010 & $\begin{array}{l}\text { PKOS'lı zayıf } \\
\text { kadınlar }\end{array}$ & 6 hasta & $\begin{array}{l}16 \text { hafta boyunca } \\
\text { günde iki kez } 600 \text { i } \\
\text { mg ALA }\end{array}$ & $\begin{array}{l}\text { Trigliserit seviyelerinda azalama, } \\
\text { insülin duyarlılığında ve adet sıklığında } \\
\text { düzelme }\end{array}$ \\
\hline $\begin{array}{l}\text { Genazzani ve ark. } \\
(92)\end{array}$ & 2012 & $\begin{array}{l}\text { PKOS'lu obez } \\
\text { kadınlar }\end{array}$ & 42 hasta & $\begin{array}{l}8 \text { hafta boyunca } \\
\text { günlük } 2 \mathrm{~g} \mathrm{MI}\end{array}$ & $\begin{array}{c}\text { LH, PRL, testosteron, insülin } \\
\text { konsantrasyonları, LH/FSH, BKI, } \\
\text { glikoz yüküne insülin cevabı anlamlı } \\
\text { derecede azalma } \\
\text { İnsülin: glikoz oranı önemli ölçüde } \\
\text { artma }\end{array}$ \\
\hline Artrini ve ark.(64) & 2013 & $\begin{array}{l}\text { PKOS'lu IVF } \\
\text { alan kadınlar }\end{array}$ & $\begin{array}{c}\text { Kontrol }=10 \\
\text { Müdahale }=10\end{array}$ & $\begin{array}{l}12 \text { hafta boyunca } \\
\text { günlük } \\
2 \text { g MI+200 mg FA } \\
\text { Kontrol grubuna } \\
200 \mathrm{mg} \mathrm{FA}\end{array}$ & $\begin{array}{c}\text { LH, PRL, insülin seviyeleri ve LH/ } \\
\text { FSH, önemli ölçüde azalma } \\
\text { HOMA indeksinde anlamlı derecede } \\
\text { azalma } \\
\text { Daha az FSH şişesi kullanılmış. } \\
\text { Düşük sayı ve daha yüksek kalitede } \\
\text { oosit elde edilmiştir. }\end{array}$ \\
\hline
\end{tabular}


Tablo I: PKOS’lu kadınlarda MI, DGI ve/veya ALA takviyesinin değerlendirilmesine yönelik yapılan bazı çalışmalar. (Devami)

\begin{tabular}{|c|c|c|c|c|c|}
\hline Yazar/kaynak & Y11 & $\begin{array}{l}\text { Hastalık/ } \\
\text { durum }\end{array}$ & $\begin{array}{l}\text { Örneklem } \\
\text { grubu }\end{array}$ & $\begin{array}{l}\text { Uygulama } \\
\text { protokolü }\end{array}$ & Sonuçlar \\
\hline $\begin{array}{l}\text { Genazzani ve ark. } \\
(93)\end{array}$ & 2014 & $\begin{array}{l}\text { PKOS'lu obez } \\
\text { kadınlar }\end{array}$ & 22 hasta & $\begin{array}{l}12 \text { hafta boyunca } \\
\text { günlük } 500 \mathrm{mg} \\
\text { DCI }\end{array}$ & $\begin{array}{c}\text { LH, androstenedion, testosteron, } \\
\text { insülin konsantrasyonları LH/FSH, } \\
\text { insülin, BKI, GnRH testine LH cevabı } \\
\text { ve glikoz yüküne insülin cevabında } \\
\text { önemli ölçüde azalma } \\
\text { İnsülin/glikoz oranında önemli ölçüde } \\
\text { artma } \\
\text { Ailesinde diyabet hikayesi olan } \\
\text { hastalarda daha büyük değişiklikler } \\
\text { gözlenmiştir. }\end{array}$ \\
\hline $\begin{array}{l}\text { Genazzani ve ark. } \\
\text { (85) }\end{array}$ & 2014 & $\begin{array}{l}\text { PKOS'lu obez } \\
\text { kadınlar }\end{array}$ & 34 hasta & $\begin{array}{l}12 \text { hafta boyunca } \\
\text { günlük } \\
400 \text { mg ALA ve } 1 \\
\text { g MI }\end{array}$ & $\begin{array}{l}\text { LH serum seviyelerinde ve LH/FSH } \\
\text { oranlarında belirgin bir azalma } \\
\text { sadece hiperinsulinemik PKOS } \\
\text { hastalarında HOMA-IR ve OGTT } \\
\text { verilen cevapta, insülin duyarlılığında } \\
\text { anlamlı bir artış } \\
\text { BKİ'de anlamlı olmayan bir azalma }\end{array}$ \\
\hline $\begin{array}{l}\text { La Marca ve ark. } \\
\text { (94) }\end{array}$ & 2015 & PKOS hastaları & 47 hasta & $\begin{array}{l}\text { 6-15 ay boyunca } \\
\text { günlük } 1-1,5 \mathrm{~g} \\
\text { DGI }\end{array}$ & $\begin{array}{l}\text { Belirgin derecede daha düzenli adet } \\
\text { döngüsü. } \\
\text { AMH ve HOMA indeksinde anlamlı } \\
\text { derecede azalma }\end{array}$ \\
\hline
\end{tabular}

Döngü sayısında ve ortalama SHBG düzeylerinde anlamlı bir artış

FAI, ortalama androstenedion ve

DHEAS seviyeleri tedaviden sonra $\begin{aligned} & \text { De cicco ve ark. } \\ & \text { (95) }\end{aligned}$
PKO17 hastaları $\quad 40$ hasta

6 ay boyunca günlük

$800 \mathrm{mg}$ ALA ve $2 \mathrm{~g}$ MI anlamlı olarak azalma

Ortalama Ferriman-Gallwey $(\mathrm{F}-\mathrm{G})$

skorunda, AMH düzeylerinde, over

hacminde ve total antral foliküler sayımda ve BKI'de anlamlı bir azalma

Gluko-insülinemik ve lipid

parametrelerinde önemli bir değişiklik olmamiştır.

İnsülin, glikoz, BKİ ve HOMA-IR

değerinin anlamlı derecede düşme

$\begin{aligned} & \text { Genazzani ve ark. } \\ & (75)\end{aligned} \quad \begin{gathered}\text { PKOS'lu obez } \\ \text { kadınlar }\end{gathered} 32$ hasta

12 hafta boyunca günlük 400 mg ALA

Üreme parametreleri ile ilgili herhangi bir değişiklik yok.

İnsülin duyarlılığını arttırma

Trigliserit plazma seviyelerinin azalma

Döngü uzunluğunda 6,12 ve 24 aylık tedavilerde önemli ölçüde azalma BKI'de sadece 6 ayda bir azalma

Fruzzetti ve ark. (84)
2019 PKOS hastaları 57 hasta
$6,12,24$ ay boyunca günlük 800 mg ALA ve 2 $\mathrm{g}$ MI
HOMA IR, açlık insülini, testosteron ve over hacminde bir değişiklik yok 6 ve 18 ay tedaviden sonra 3 saatlik OGTT'ye insülin cevabında düzelme 
Tablo I: PKOS’lu kadınlarda MI, DCI ve/veya ALA takviyesinin değerlendirilmesine yönelik yapılan bazı çalışmalar. (Devami)

\begin{tabular}{|c|c|c|c|c|c|}
\hline Yazar/kaynak & Yil & $\begin{array}{c}\text { Hastallk/ } \\
\text { durum }\end{array}$ & $\begin{array}{l}\text { Örneklem } \\
\text { grubu }\end{array}$ & $\begin{array}{l}\text { Uygulama } \\
\text { protokolü }\end{array}$ & Sonuçlar \\
\hline $\begin{array}{l}\text { Genazzani ve ark. } \\
\text { (96) }\end{array}$ & 2019 & $\begin{array}{l}\text { PKOS'lu şişman/ } \\
\text { obez kadınlar }\end{array}$ & 90 hasta & $\begin{array}{l}12 \text { hafta boyunca } \\
\text { günlük } \\
\text { Ya } 400 \text { mg ALA } \\
\text { ya } 1 \mathrm{~g} \mathrm{MI} \\
\text { ya da } \\
400 \text { mg ALA+1 g } \\
\text { MI }\end{array}$ & $\begin{array}{l}\text { Tüm tedaviler spesifik pozitif etkiler } \\
\text { göstermiştir: ailesinde diyabet öyküsü } \\
\text { olmayan PKOS'lularda MI daha fazla } \\
\text { hormonal profil ve OGTT modüle } \\
\text { etmiştir, } \\
\text { ALA tüm hastalarda OGTT ve } \\
\text { metabolik parametrelere insülin } \\
\text { cevabını arttırmış fakat üreme } \\
\text { hormonları üzerinde hiçbir etkisi } \\
\text { olmamıştır. } \\
\text { MI+ALA tüm hastalarda hem } \\
\text { hormonal ve metabolik olarak hem de } \\
\text { OGTT’ye insülin cevabında iyileşme } \\
\text { sağlamıştır. }\end{array}$ \\
\hline
\end{tabular}

PKOS: polikistik over sendromu, $\boldsymbol{M I}$ : myoinositol, $\boldsymbol{F A}$ : folik asit, $\boldsymbol{D C I}$ : d-chiroinositol, $\boldsymbol{L H}$ : luteinlestici hormon, $\boldsymbol{P R L}:$ prolaktin, $\boldsymbol{F S H}:$ folikül stimüle edici hormon, HOMA-IR: insülin direnci indeksi, BKI: beden kütle indeksi, $\boldsymbol{A L A}$ : alfa lipoik asit, IVF: in vitro fertilizasyon, OGTT: oral glukoz tolerans testi, $\boldsymbol{A M H}$ : anti-müllerer hormon, $\boldsymbol{S H B G : ~ s e k s ~ h o r m o n u ~ b a g ̆ l a y n c ı ~ g l o b u ̈ l i n , ~} \boldsymbol{F A I}$ : Serbest androjen indeksi, DHEAS: Dehidroepiandrosteron sülfat.

MI, DCI ve ALA'nın kullanıldığı bazı çalışmalar özetlenmiştir $(47,64,75,83-85,92-96)$.

\section{SONUÇ}

Mevcut kanitlar, inositollerin PKOS hastalarında metabolik ve over fonksiyonunu iyileştirebileceği, yumurtlama oranının yanı sıra hormonal ve glisemik profillerin iyileştirilmesinde belirgin faydalar sağladığını göstermektedir. Ayrıca, adet döngüsünü düzenleyerek, bu kadınlarda endometrial hiperplazi yükünü azaltma potansiyeline sahiptir. Alfa lipoik asit, jinekolojide ümit verici bir antioksidandır. PKOS'lu hastalarda yapılan çalışmalar, ALA takviyesinin ID'ye olumlu etkisinin yanında doğurganlık üzerindeki etkileriyle birlikte amenore ve hiperandrojenizmde iyileşme sağladığını göstermektedir. ALA ve MI kombine tedavisi ise PKOS'lu kadınların menstrüel düzenliliğini olumlu yönde etkileyebilir, metabolik profilin iyileştirilmesinde fayda sağlayabilir. Şu anda, ALA ve MI'nın ID üzerindeki etkileri ve çalışma mekanizmaları kapsamlı olarak açıklanamamak- tadır. ALA ve MI'nın PKOS'lu kadınlarda uzun vadede üreme fizyolojisi, hormonal ve metabolik parametreler üzerindeki etkilerini değerlendirmek, etki ve çalışma mekanizmalarını daha iyi araştırmak için geniş çaplı örnekleme sahip uzun süreli daha fazla araştırmaya ihtiyaç vardır.

\section{Yazar Katkı Beyanı}

Tasarım: Selma FIRAT, Mehmet FISUNOĞLU

Planlanma: Selma FIRAT, Mehmet FISUNOĞLU

Literatür İnceleme: Selma FIRAT

Makale Yazma: Selma FIRAT, Mehmet FISUNOĞLU

Makale Değerlendirme: Selma FIRAT, Mehmet FISUNOĞLU

\section{Çıkar Çatışması Beyanı}

Yazarlar ya da yazı ile ilgili herhangi bir çıkar çatışması yoktur.

Herhangi bir kurum veya kuruluştan destek alınmamıştır. 


\section{KAYNAKLAR}

1. Rotterdam ESHRE/ASRM-Sponsored PCOS Consensus Workshop Group. Revised 2003 consensus on diagnostic criteria and long-term health risks related to polycystic ovary syndrome. Fertil Steril 2004;81(1):19-25.

2. Dumesic DA, Oberfield SE, Stener-Victorin E, Marshall JC, Laven JS, Legro RS. Scientific statement on the diagnostic criteria, epidemiology, pathophysiology, and molecular genetics of polycystic ovary syndrome. Endocr Rev 2015;36(5):487-525.

3. Escobar-Morreale HF. Polycystic ovary syndrome: definition, aetiology, diagnosis and treatment. Nat Rev Endocrinol 2018;14(5):270.

4. March WA, Moore VM, Willson KJ, Phillips DI, Norman RJ,Davies MJ. The prevalence of polycystic ovarysyndrome in a community sample assessed under contrasting diagnostic criteria. Hum Reprod 2010;25(2):544-51.

5. Dewailly D. Diagnostic criteria for PCOS: is there a need for a rethink? Best Pract Res Clin Obstet Gynaecol 2016;37:5-11.

6. Nardo L, Patchava S, Laing I. Polycystic ovary syndrome: pathophysiology, molecular aspects and clinical implications. Panminerva Med 2008;50(4):267-78.

7. Xita N, Tsatsoulis A. Fetal programming of polycystic ovary syndrome by androgen excess: evidence from experimental, clinical, and genetic association studies. J Clin Endocrinol Metab 2006;91(5):1660-6.

8. Teede H, Misso M, Costello M, Dokras A, Laven J, Moran L, Piltonen T, Norman RJ. Recommendations from the international evidence-based guideline for the assessment and management of polycystic ovary syndrome. Fertil Steril 2018;110(3):364-79..

9. Pundir J, Psaroudakis D, Savnur P, Bhide P, Sabatini L, Teede H, Coomarasamy A, Thangaratinam S. Inositol treatment of anovulation in women with polycystic ovary syndrome: a meta-analysis of randomised trials. BJOG 2018;125(3):299-308.

10. Unfer V, Carlomagno G, Dante G, Facchinetti F. Effects of myo-inositol in women with PGOS: a systematic review of randomized controlled trials. Gynecol Endocrinol 2012;28(7):509-15.

11. Groze ML, Soulage CO. Potential role and therapeutic interests of myo-inositol in metabolic diseases. Biochimie 2013;95(10):1811-27

12. Fruzzetti F, Benelli E, Fidecicchi T, Tonacchera M. Clinical and metabolic effects of alpha-lipoic acid associated with two different doses of myo-inositol in women with polycystic ovary syndrome. Int J Endocrinol 2020:2901393

13. Bizzarri M, Fuso A, Dinicola S, Cucina A, Bevilacqua A. Pharmacodynamics and pharmacokinetics of inositol (s) in health and disease. Expert Opin Drug Metab Toxicol 2016;12(10):1181-96
14. Heimark D, McAllister J, Larner J. Decreased myoinositol to chiro-inositol $(\mathrm{M} / \mathrm{C}$ ) ratios and increased $\mathrm{M} / \mathrm{C}$ epimerase activity in PCOS theca cells demonstrate increased insulin sensitivity compared to controls. Endocr J 2014:61(2):111-7.

15. Sun T-h, Heimark DB, Nguygen T, Nadler JL, Larner J. Both myo-inositol to chiro-inositol epimerase activities and chiro-inositol to myo-inositol ratios are decreased in tissues of GK type 2 diabetic rats compared to Wistar controls. Biochem Biophys Res Commun 2002;293(3):1092-8.

16. Baillargeon J-P, Diamanti-Kandarakis E, Ostlund RE, Apridonidze T, Iuorno MJ, Nestler JE. Altered D-chiroinositol urinary clearance in women with polycystic ovary syndrome. Diabetes care 2006;29(2):300-5.

17. Carlomagno G, Unfer V, Roseff S. The D-chiro-inositol paradox in the ovary. Fertil Steril 2011;95(8):2515-6.

18. Unfer V, Nestler JE, Kamenov ZA, Prapas N, Facchinetti F. Effects of inositol (s) in women with PCOS: a systematic review of randomized controlled trials. Int $\mathrm{J}$ Endocrinol 2016:1849162.

19. Crawford TJ, Crowther CA, Alsweiler J, Brown J. Antenatal dietary supplementation with myo-inositol in women during pregnancy for preventing gestational diabetes. Cochrane Database Syst Rev 2015:Cd011507.

20. Shay KP, Moreau RF, Smith EJ, Smith AR, Hagen TM. Alpha-lipoic acid as a dietary supplement: molecular mechanisms and therapeutic potential. Biochim Biophys Acta 2009;1790(10):1149-60.

21. Golbidi S, Badran M, Laher I. Diabetes and alpha lipoic acid. Front Pharmacol 2011;2:69.

22. Ma X, He P, Sun P, Han P. Lipoic acid: an immunomodulator that attenuates glycinin-induced anaphylactic reactions in a rat model. J Agric Food Chem 2010;58(8):5086-92.

23. Lee WJ, Song K-H, Koh EH, Won JC, Kim HS, Park H-S, Kim MS, Kim SW, Lee KU, Park JY. a-Lipoic acid increases insulin sensitivity by activating AMPK in skeletal muscle. Biochem Biophys Res Commun 2005;332(3):88591.

24. Shen QW, Zhu MJ, Tong J, Ren J, Du M. Ca2+/ calmodulin-dependent protein kinase kinase is involved in AMP-activated protein kinase activation by a-lipoic acid in C2C12 myotubes. Am J Physiol Cell Physiol 2007;293(4):1395-403.

25. Steinberg GR, Kemp BE. AMPK in health and disease. Physiol Rev 2009;89(3):1025-78.

26. Di Tucci C, Di Feliciantonio M, Vena F, Capone C, Schiavi MC, Pietrangeli D, Muzii L, Benedetti Panici P. Alpha lipoic acid in obstetrics and gynecology. Gynecol Endocrinol 2018;34(9):729-33.

27. Goodarzi MO, Dumesic DA, Chazenbalk G, Azziz R. Polycystic ovary syndrome: etiology, pathogenesis and diagnosis. Nat Rev Endocrinol 2011;7(4):219-31. 
28. Rondanelli M, Perna S, Faliva M, Monteferrario F, Repaci E, Allieri F. Focus on metabolic and nutritional correlates of polycystic ovary syndrome and update on nutritional management of these critical phenomena. Arch Gynecol Obstet 2014;290(6):1079-92.

29. Galazis N, Docheva N, Nicolaides KH, Atiomo W. Proteomic biomarkers of preterm birth risk in women with polycystic ovary syndrome (PCOS): a systematic review and biomarker database integration. PloS One 2013;8(1):e53801.

30. Kriedt KJ, Alchami A, Davies MC. PCOS: diagnosis and management of related infertility. Obstetrics, Gynaecology \& Reproductive Medicine 2018;29:1

31. Yıldızhan B, Anık İlhan G. Polikistik Over Sendromunda Uzun Dönem Sağlık Sorunları. Van Tıp Derg 2016;23(3):301-6.

32. Balen AH. Polycystic ovary syndrome (PCOS). The Obstetrician \& Gynaecologist 2017;19:1 19-29.

33. Anagnostis P, Tarlatzis BC, Kauffman RP. Polycystic ovarian syndrome (PCOS): Long-term metabolic consequences. Metabolism 2018;86:33-43.

34. Hoeger K. Obesity and weight loss in polycystic ovary syndrome. Obstetrics and gynecology clinics of North America 2001;28(1):85-97.

35. Martinez-Bermejo E, Luque-Ramirez M, EscobarMorreale HF. Obesity and the polycystic ovary syndrome. Minerva Endocrinol 2007;32(3):129-40.

36. Panidis D, Farmakiotis D, Rousso D, Kourtis A, Katsikis I, Krassas G. Obesity, weight loss, and the polycystic ovary syndrome: effect of treatment with diet and orlistat for 24 weeks on insulin resistance and androgen levels. Fertil Steril 2008;89(4):899-906.

37. Moran LJ, Brinkworth GD, Norman RJ. Dietary therapy in polycystic ovary syndrome. Semin Reprod Med 2008 Jan;26(1):85-92.

38. Dessi A, Fanos V. Myoinositol: a new marker of intrauterine growth restriction? J Obstet Gynaecol 2013;33(8):776-80.

39. Malvasi A, Casciaro F, Minervini M, Kosmas I, Mynbaev O, Pacella E, Monti Condesnitt V, Creanza A, Di Renzo GC, Tinelli A. Myo-inositol, D-chiro-inositol, folic acid and manganese in second trimester of pregnancy: a preliminary investigation. Eur Rev Med Pharmacol Sci 2014;18(2):270-4.

40. Stracquadanio M, Ciotta L, Palumbo MA. Effects of myo-inositol, gymnemic acid, and L-methylfolate in polycystic ovary syndrome patients. Gynecol Endocrinol 2018;34(6):495-501.

41. Celentano C, Matarrelli B, Mattei PA, Pavone G, Vitacolonna E, Liberati M. Myo-Inositol Supplementation to Prevent Gestational Diabetes Mellitus. Curr Diab Rep 2016;16(3):30.
42. Schlemmer U, Frølich W, Prieto RM, Grases F. Phytate in foods and significance for humans: food sources, intake, processing, bioavailability, protective role and analysis. Mol Nutr Food Res 2009;53(2):330-75.

43. Condorelli R, La Vignera S, Mongioì L, Vitale S, Laganà A, Cimino L, Calogero AE. Myo-inositol as a male fertility molecule: speed them up. Eur Rev Med Pharmacol Sci 2017;21(2):30-5.

44. Monastra G, Unfer V, Harrath AH, Bizzarri M. Combining treatment with myo-inositol and D-chiroinositol (40: 1) is effective in restoring ovary function and metabolic balance in PCOS patients. Gynecol Endocrinol 2017;33(1):1-9.

45. Facchinetti F, Bizzarri M, Benvenga S, D’Anna R, Lanzone A, Soulage C, Di Renzo GC, Hod M, Cavalli P, Chiu TT, Kamenov ZA, Bevilacqua A, Carlomagno G, Gerli S, Oliva MM, Devroey P. Results from the International Consensus Conference on Myo-inositol and d-chiro-inositol in Obstetrics and Gynecology: the link between metabolic syndrome and PCOS. Eur J Obstet Gynecol Reprod Biol 2015;195:72-6.

46. Costantino D, Minozzi G, Minozzi E, Guaraldi C. Metabolic and hormonal effects of myo-inositol in women with polycystic ovary syndrome: a double-blind trial. Eur Rev Med Pharmacol Sci 2009;13(2):105-10.

47. Genazzani AD, Lanzoni C, Ricchieri F, Jasonni VM. Myoinositol administration positively affects hyperinsulinemia and hormonal parameters in overweight patients with polycystic ovary syndrome. Gynecol Endocrinol 2008;24(3):139-44.

48. Minozzi M, Nordio M, Pajalich R. The combined therapy myo-inositol plus D-chiro-inositol, in a physiological ratio, reduces the cardiovascular risk by improving the lipid profile in PCOS patients. Eur Rev Med Pharmacol Sci 2013;26:5-1.

49. Nordio M, Proietti E. The combined therapy with myoinositol and D-chiro-inositol reduces the risk of metabolic disease in PGOS overweight patients compared to myoinositol supplementation alone. Eur Rev Med Pharmacol Sci 2012;16(5):575-81.

50. Gerli S, Papaleo E, Ferrari A, Di Renzo G. Randomized, double blind placebo-controlled trial: effects of myoinositol on ovarian function and metabolic factors in women with PCOS. Eur Rev Med Pharmacol Sci 2007;11(5):347-54.

51. Groze ML, Vella RE, Pillon NJ, Soula HA, Hadji L, Guichardant M, Soulage CO. Chronic treatment with myo-inositol reduces white adipose tissue accretion and improves insulin sensitivity in female mice. J Nutr Biochem 2013;24(2):457-66.

52. Unfer V, Carlomagno G, Papaleo E, Vailati S, Candiani M, Baillargeon JP. Hyperinsulinemia alters myoinositol to d-chiroinositol ratio in the follicular fluid of patients with PCOS. Reprod Sci 2014;21(7):854-8. 
53. Larner J. D-chiro-inositol-its functional role in insulin action and its deficit in insulin resistance. Int $\mathrm{J}$ Exp Diabetes Res 2002;3(1):47-60.

54. Minozzi M, D’Andrea G, Unfer V. Treatment of hirsutism with myo-inositol: a prospective clinical study. Reprod Biomed Online 2008;17(4):579-82.

55. Papaleo E, Unfer V, Baillargeon JP, De Santis L, Fusi F, Brigante C, Marelli G, Cino I, Redaelli A, Ferrari A. Myoinositol in patients with polycystic ovary syndrome: a novel method for ovulation induction. Gynecol Endocrinol 2007;23(12):700-3.

56. Raffone E, Rizzo P, Benedetto V. Insulin sensitiser agents alone and in co-treatment with r-FSH for ovulation induction in PCOS women. Gynecol Endocrinol 2010;26(4):275-80.

57. Lowther KM, Weitzman VN, Maier D, Mehlmann LM. Maturation, fertilization, and the structure and function of the endoplasmic reticulum in cryopreserved mouse oocytes. Biol Reprod 2009;81(1):147-54.

58. Chiu TTY, Rogers MS, Briton-Jones C, Haines C. Effects of myo-inositol on the in-vitro maturation and subsequent development of mouse oocytes. Hum Reprod 2003;18(2):408-16.

59. Colazingari S, Fiorenza MT, Carlomagno G, Najjar R, Bevilacqua A. Improvement of mouse embryo quality by myo-inositol supplementation of IVF media. J Assist Reprod Genet 2014;31(4):463-9.

60. Ciotta L, Stracquadanio M, Pagano I, Carbonaro A, Palumbo M, Gulino F. Effects of myo-inositol supplementation on oocyte's quality in PCOS patients: a double blind trial. Eur Rev Med Pharmacol Sci 2011;15(5):509-14.

61. Colazingari S, Treglia M, Najjar R, Bevilacqua A. The combined therapy myo-inositol plus D-chiro-inositol, rather than D-chiro-inositol, is able to improve IVF outcomes: results from a randomized controlled trial. Arch Gynecol Obstet 2013;288(6):1405-11.

62. Mendoza N, Diaz-Ropero MP, Aragon M, Maldonado V, Llaneza P, Lorente J, Mendoza-Tesarik R, MaldonadoLobon J, Olivares M. Fonolla J. Comparison of the effect of two combinations of myo-inositol and D-chiro-inositol in women with polycystic ovary syndrome undergoing ICSI: a randomized controlled trial. Gynecol Endocrinol 2019;35(8):695-700.

63. Isabella R, Raffone E. CONGERN: Does ovary need D-chiro-inositol? Journal of Ovarian Research. J Ovarian Res 2012;5(1):14.

64. Artini PG, Di Berardino O, Papini F, Genazzani A, Simi G, Ruggiero M, Cela V. Endocrine and clinical effects of myo-inositol administration in polycystic ovary syndrome. A randomized study. Gynecol Endocrinol 2013;29(4):3759.
65. Sene AA, Tabatabaie A, Nikniaz H, Alizadeh A, Sheibani K, Alisaraie MM, Tabatabaie M, Ashrafi M, Amjadi F. The myo-inositol effect on the oocyte quality and fertilization rate among women with polycystic ovary syndrome undergoing assisted reproductive technology cycles: a randomized clinical trial. Arch Gynecol Obstet 2019;299(6):1701-7.

66. Elibol E, Akdevelioğlu Y. İnositol ve Kadın Üreme Sağlığı. Turkiye KlinikleriJ Health Sci 2017;2(3):201-6.

67. Mayr JA, Feichtinger RG, Tort F, Ribes A, Sperl W. Lipoic acid biosynthesis defects. J Inherit Metab Dis 2014;37(4):553-63.

68. Solmonson A, De Berardinis RJ. Lipoic acid metabolism and mitochondrial redox regulation. J Biol Chem 2018;293(20):7522-30.

69. Tibullo D, Volti GL, Giallongo C, Grasso S, Tomassoni D, Anfuso CD, Lupo G, Amenta F, Avola R, Bramanti V. Biochemical and clinical relevance of alpha lipoic acid: antioxidant and anti-inflammatory activity, molecular pathways and therapeutic potential. Inflamm Res 2017;66(11):947-59.

70. Gorąca A, Huk-Kolega H, Piechota A, Kleniewska P, Ciejka E, Skibska B. Lipoic acid-biological activity and therapeutic potential. Pharmacol Rep 2011;63(4):849-58.

71. Mohammadi V, Khalili M, Eghtesadi S, "Dehghani S, Jazayeri S, Aghababaee S, Sabour H, Saberi H, Eghtesadi M, Gohari MR. The effect of alpha-lipoic acid (ALA) supplementation on cardiovascular risk factors in men with chronic spinal cord injury: a clinical trial. Spinal Cord 2015;53(8):621-4.

72. Namazi N, Larijani B, Azadbakht L. Alpha-lipoic acid supplement in obesity treatment: A systematic review and meta-analysis of clinical trials. Clin Nutr 2018;37(2):41928.

73. Bilska A, Wlodek L. Lipoic acid-the drug of the future. Pharmacol Rep 2005;57(5):570-7.

74. Kim W-J, KangJ-Y, Kwon D-K, Song Y-J, Lee K-H. Effects of a-lipoic acid supplementation on malondialdehyde contents and superoxide dismutase in rat skeletal muscles. Food Sci. Biotechnol 2011;20(4):1133-6.

75. Genazzani AD, Shefer K, Della Casa D, Prati A, Napolitano A, Manzo A, Despini G, Simoncini T. Modulatory effects of alpha-lipoic acid (ALA) administration on insulin sensitivity in obese PCOS patients. J Endocrinol Invest 2018:41(5):583-590.

76. Beckman JA, Creager MA, Libby P. Diabetes and atherosclerosis: epidemiology, pathophysiology, and management. JAMA 2002;287(19):2570-81 .

77. Clavreul N, Bachschmid MM, Hou X, Shi C, Idrizovic A, Ido Y, Pimentel D, Cohen RA. S-glutathiolation of p21ras by peroxynitrite mediates endothelial insulin resistance caused by oxidized low-density lipoprotein. Arterioscler Thromb Vasc Biol 2006;26(11):2454-61. 
78. Eason R, Archer H, Akhtar S, Bailey CJ. Obesity, Metabolism. Lipoic acid increases glucose uptake by skeletal muscles of obese-diabetic ob/ob mice. Diabetes Obes Metab 2002;4(1):29-35.

79. Ghibu S, Richard C, Vergely C, Zeller M, Cottin Y, Rochette L. Antioxidant properties of an endogenous thiol: alpha-lipoic acid, useful in the prevention of cardiovascular diseases. J Cardiovasc Pharmacol 2009;54(5):391-8.

80. Gomes MB, Negrato CA. Alpha-lipoic acid as a pleiotropic compound with potential therapeutic use in diabetes and other chronic diseases. Diabetol Metab Syndr 2014;6(1):80.

81. Scaramuzza A, Giani E, Redaelli F, Ungheri S, Macedoni M, Giudici V, Bosetti A, Ferrari M, Zuccotti GV. Alphalipoic acid and antioxidant diet help to improve endothelial dysfunction in adolescents with type 1 diabetes: a pilot trial. J Diabetes Res 2015;474561.

82. Konrad D, Somwar R, Sweeney G, Yaworsky K, Hayashi M, Ramlal T, Klip A. The antihyperglycemic drug a-lipoic acid stimulates glucose uptake via both GLUT4 translocation and GLUT4 activation: potential role of p38 mitogen-activated protein kinase in GLUT4 activation. Diabetes 2001;50(6):1464-71.

83. Masharani U, Gjerde C, Evans JL, Youngren JF, Goldfine ID. Effects of controlled-release alpha lipoic acid in lean, nondiabetic patients with polycystic ovary syndrome. J Diabetes Sci Technol 2010;4(2):359-64.

84. Fruzzetti F, Fidecicchi T, Palla G, Gambacciani M. Long-term treatment with alpha-lipoic acid and myoinositol positively affects clinical and metabolic features of polycystic ovary syndrome. Gynecol Endocrinol 2020;36(2):152-155.

85. Genazzani AD, Despini G, Santagni S, Prati A, Rattighieri E, Chierchia E, Simoncini T. Effects of a combination of alpha lipoic acid and myo-inositol on insulin dynamics in overweight/obese patients with PCOS. Endocrinol Metab Synd 2014;3(3):1000140.

86. Cappelli V, Di AS, Musacchio M, De VL. Evaluation of a new association between insulin-sensitizers and a-lipoic acid in obese women affected by PCOS. Minerva Ginecol 2013;65(4):425-33.

87. Rago R, Marcucci I, Leto G, Caponecchia L, Salacone P, Bonanni P, Fiori C, Sorrenti G, Sebastianelli A. Effect of myo-inositol and alpha-lipoic acid on oocyte quality in polycystic ovary syndrome non-obese women undergoing in vitro fertilization: a pilot study. J Biol Regul Homeost Agents 2015;29(4):913-23.
88. Artini PG, Obino MER, Micelli E, Malacarne E, Vacca C, Papini F, Gela V. Effect of d-chiro-inositol and alpha-lipoic acid combination on $\mathrm{COH}$ outcomes in overweight/obese PCOS women. Gynecol Endocrinol 2020;36(9):755-9.

89. Morgante G, Cappelli V, Di AS, Massaro M, De VL. Polycystic ovary syndrome (PCOS) and hyperandrogenism: the role of a new natural association. Minerva Ginecol 2015;67(5):457-63.

90. Cianci A, Panella M, Fichera M, Falduzzi C, Bartolo M, Caruso S. D-chiro-Inositol and alpha lipoic acid treatment of metabolic and menses disorders in women with PCOS. Gynecol Endocrinol 2015;31(6):483-6.

91. Cirillo F, Catellani C, Lazzeroni P, Sartori C, Tridenti G, Vezzani C, Fulghesu AM, Madeddu E, Amarri S, Street ME. HMGB1 is increased in adolescents with polycystic ovary syndrome (PCOS) and decreases after treatment with myo-inositol (MYO) in combination with alphalipoic acid (ALA). Gynecol Endocrinol 2020;36(7):588-93.

92. Genazzani AD, Prati A, Santagni S, Ricchieri F, Chierchia E, Rattighieri E, Campedelli A, Simoncini T, Artini PG. Differential insulin response to myo-inositol administration in obese polycystic ovary syndrome patients. Gynecol Endocrinol 2012;28(12):969-73.

93. Genazzani AD, Santagni S, Rattighieri E, Chierchia E, Despini G, Marini G, Prati A, Simoncini T. Modulatory role of D-chiro-inositol (DCI) on LH and insulin secretion in obese PCOS patients. Gynecol Endocrinol 2014;30(6):438-43.

94. La Marca A, Grisendi V, Dondi G, Sighinolfi G, Cianci A. The menstrual cycle regularization following D-chiroinositol treatment in PCOS women: a retrospective study. Gynecol Endocrinol 2015;31(1):52-6.

95. De Cicco S, Immediata V, Romualdi D, Policola C, Tropea A, Di Florio C, Tagliaferri V, Scarinci E, Della Casa S, Lanzone A, Apa R. Myoinositol combined with alpha-lipoic acid may improve the clinical and endocrine features of polycystic ovary syndrome through an insulinindependent action. Gynecol Endocrinol 2017;33(9):698701.

96. Genazzani AD, Prati A, Marchini F, Petrillo T, Napolitano A, Simoncini T. Differential insulin response to oral glucose tolerance test (OGTT) in overweight/obese polycystic ovary syndrome patients undergoing to myoinositol (MYO), alpha lipoic acid (ALA), or combination of both. Gynecol Endocrinol 2019:35(12):1088-93. 